\title{
Studies of corrosion on AA 6061 and AZ 61 friction stir welded plates
}

\author{
Raguraman, D. ${ }^{a}{ }^{*}$, Muruganandam, D. ${ }^{a},{ }^{\prime}$ Kumaraswami Dhas, L.A. ${ }^{b}$ \\ ${ }^{a}$ Department of Production Engineering, Sri Sairam Engineering College, Chennai, India \\ bepartment of Mining Machinery and Engineering, Indian Institute of Technology Dhanbad (ISM), Dhanbad, India
}

\begin{abstract}
A B S T R A C T
A remarkably new welding process, namely friction stir welding (FSW) has reached a tremendous research interest on the present decade due to bonding of similar or dissimilar materials at solidus state. This welding technique is environment friendly and versatile. In specific, FSW can be used to join the high strength aluminium alloys and other dissimilar alloys that are difficult to weld by conventional fusion welding. The process parameters have a major role in changing the characterisation of the joint. In this work, three parameters of the weld, namely rotational speed (rpm), axial load $(\mathrm{kN})$, and weld speed $(\mathrm{mm} / \mathrm{min})$ are considered. Three pairs of AA 6061 and AZ 61 plates were welded with three different sets of these parameters. The welded zone was immersed in corrosive solution of $\mathrm{NaOH}$ for six months period. Corrosion behaviour was studied with the help of SEM and EDAX. Through this investigation, the importance of weld parameters control for the study of effects on the susceptibility for corrosion on the welded region can be sought.
\end{abstract}

(c) 2016 PEI, University of Maribor. All rights reserved.

\author{
ARTICLE INFO \\ Keywords: \\ Friction stir welding \\ AA 6061 \\ AZ 61 \\ Tool geometry \\ Corrosion behaviour \\ *Corresponding author: \\ raguraman150807@gmail.com \\ (Raguraman, D.) \\ Article history: \\ Received 15 December 2015 \\ Revised 24 May 2016 \\ Accepted 16 June 2016
}

\section{References}

[1] Fahimpour, V., Sadrnezhaad, S.K., Karimzadeh, F. (2012). Corrosion behavior of aluminum 6061 alloy joined by friction stir welding and gas tungsten arc welding methods, Materials \& Design, Vol. 39, 329-333, doi: 10.1016/ j.matdes.2012.02.043.

[2] Mathers, G. (2002). The welding of aluminium and its alloys, Woodhead Publishing Limited, Abington, Cambridge, England.

[3] Corral, J., Trillo, E.A., Li, Y., Murr, L.E. (2000). Corrosion of friction-stir welded aluminum alloys 2024 and 2195, Journal of Materials Science Letters, Vol. 19, No. 23, 2117-2122, doi: 10.1023/A:1026710422951.

[4] Nagasawa, T., Otsuka, M., Yokota, T., Ueki, T. (2000). Structure and mechanical properties of friction stir weld joints of magnesium alloy AZ31. In: Mathaudhu, S.N., Luo, A.A., Neelameggham, N.R., Nyberg, E.A, Sillekens, W.H. (eds.), Essential Readings in Magnesium Technology, John Wiley \& Sons, 517-521, doi: 10.1002/9781118859803. ch84.

[5] Thirugnanaselvi, S., Kuttirani, S., Emelda, A.R. (2014). Effect of schiff base as corrosion inhibitor on AZ31 magnesium alloy in hydrochloric acid solution, Transactions of Nonferrous Metals Society of China, Vol. 24, No. 6, 19691977, doi: 10.1016/S1003-6326(14)63278-7.

[6] Song, G., Atrens, A. (2003). Understanding magnesium corrosion-A framework for improved alloy performance, Advanced Engineering Materials, Vol. 5, No. 12, 837-858, doi: 10.1002/adem.200310405.

[7] Shaw, B.A. (2003). Corrosion resistance of magnesium alloys, In: Cramer, S.D., Covino, B.S. (eds.), ASM Handbook Vol. 13A: Corrosion: Fundamentals, Testing, and Protection, ASM International Handbook Committee, Materials Park Campus, Ohio, USA, 692-696.

[8] Hattingh, D.G., Blignault, C., Van Niekerk, T.I., James, M.N. (2008). Characterization of the influences of FSW tool geometry on welding forces and weld tensile strength using an instrumented tool, Journal of Materials Processing Technology, Vol. 203, No. 1-3, 46-57, doi: 10.1016/i.jmatprotec.2007.10.028. 
[9] Ramanjaneyulu, K., Madhusudhan R.G., Venugopal R.A., Markandeya, R. (2013). Structure-property correlation of AA2014 friction stir welds: Role of tool pin profile, Journal of Materials Engineering and Performance, Vol. 22, No. 8, 2224-2240, doi: 10.1007/s11665-013-0512-4.

[10] Nicholas, E.D., Thomas, W.M. (1998). A review of friction processes for aerospace applications, International Journal of Materials Product Technology, Vol. 13, No. 1-2, 45-55.

[11] Threadgill, P.L., Leonard, A.J., Shercliff, H.R., Withers, P.J. (2009). Friction stir welding of aluminium alloys, International Materials Reviews, Vol. 54, No. 2, 49-93, doi: 10.1179/174328009X411136.

[12] Gharavi, F., Matori, K.A., Yunus, R., Othman, N.K., Fadaeifard, F. (2015). Corrosion behavior of Al6061 alloy weldment produced by friction stir welding process, Journal of Materials Research and Technology, Vol. 4, No. 3, 314-322, doi: 10.1016/i.jmrt.2015.01.007.

[13] Sharma, C., Dwivedi, D.K., Kumar, P. (2015). Influences of friction stir welding on the microstructure, mechanical and corrosion behaviour of Al-Zn-Mg aluminium alloy 7039, Engineering Review, Vol. 35, No. 3, 267-274.

[14] Paglia, C.S., Buchheit, R.G. (2008). A look in the corrosion of aluminium alloy friction stir welds, Scripta Materialia, Vol. 58, No. 5, 383-387, doi: 10.1016/i.scriptamat.2007.10.043.

[15] Mishra, R.S., Ma, Z.Y. (2005). Friction stir welding and processing, Materials Science and Engineering: R: Reports, Vol. 50, No. 1-2, 1-78, doi: 10.1016/i.mser.2005.07.001.

[16] Thomas, W.M., Dolby, R.E. (2002). Friction stir welding developments, In: 6th International Conference on Trends in Welding Research, Pine Mountain, Georgia, USA, from https://www.researchgate.net/publication/ 273060095 Friction Stir Welding Developments, accessed November 7, 2015.

[17] Gao, Z., Wang, P., Cheng, D., Niu, J., Sommitsch, C. (2015). Numerical simulation of material flow in AA6082 during friction stir spot welding, Engineering Review, Vol. 35, No. 3, 283-289.

[18] Indira Rani, M., Marpu, R.N., Kumar, A.C.S. (2011). A study of process parameters of friction stir welded AA 6061 aluminum alloy in 0 and T6 conditions, ARPN Journal of Engineering and Applied Sciences, Vol. 6, No. 2, 61-66.

[19] Raguraman, D., Muruganandam, D., Kumaraswamy, L.K. (2014). Corrosion study in friction stir welded plates of AA6061 and AA7075, International Journal of ChemTech Research, Vol. 6, No. 4, 2577-2582. 


\section{APEM}

\title{
Študija korozijske obstojnosti plošč AA 6061 in AZ 61, varje- nih s postopkom varjenja $s$ trenjem in mešanjem
}

\author{
Raguraman, D. ${ }^{\mathrm{a},{ }^{*}}$, Muruganandam, D. ${ }^{\mathrm{a}}$, Kumaraswami Dhas, L.A. ${ }^{\mathrm{b}}$ \\ ${ }^{a}$ Department of Production Engineering, Sri Sairam Engineering College, Chennai, India \\ ${ }^{b}$ Department of Mining Machinery and Engineering, Indian Institute of Technology Dhanbad (ISM), Dhanbad, India
}

\section{POVZETEK}

Varjenje s trenjem in mešanjem se je v zadnjem desetletju zelo razmahnilo, saj omogoča spajanje podobnih ali različnih materialov v trdnem stanju. Postopek je ekološko prijazen in vsestranski. S trenjem in mešanjem lahko spajamo visokotrdnostne aluminijeve zlitine in preostale različne materiale, ki jih s konvencionalnimi postopki težko varimo. Procesni parametri imajo največji vpliv na lastnosti zvarnega spoja. $\mathrm{V}$ tej raziskavi smo uporabili tri procesne parametre in sicer hitrost vrtenja (rpm), aksialno obremenitev ( $\mathrm{kN})$ in hitrost varjenja ( $\mathrm{mm} / \mathrm{min})$. Varili smo tri pare preizkušancev (plošč) iz materialov AA 6061 in AZ 61, uporabili pa smo tri različne kombinacije parametrov. Nato smo zvarni spoj za šest mesecev potopili v korozivno raztopino $\mathrm{NaOH}$. Stopnjo korozije smo ugotavljali s postopkoma SEM in EDAX. Raziskava je pokazala pomen in vpliv nastavljenih varilnih parametrov na korozijsko obstojnost zvarnega spoja.

(C) 2016 PEI, University of Maribor. All rights reserved.

\begin{tabular}{l} 
P O D A T K I O Č L A N K U \\
\hline Ključne besede: \\
Varjenje s trenjem in mešanjem \\
AA 6061 \\
AZ 61 \\
Oblika orodja \\
Korozija \\
*Kontaktna oseba: \\
raguraman150807@gmail.com \\
(Raguraman, D.) \\
Zgodovina članka: \\
Prejet 15. decembra 2015 \\
Popravljen 24. maja 2016 \\
Sprejet 16. junija 2016
\end{tabular}

